\title{
Methods of using Authoring Tools in the Formation of Media-Creative Competences of Future Lawyers
}

\author{
Pozilova Shakhnoza Khaydaraliyevna, Karimov Akramjon Zaynobidinovich
}

\begin{abstract}
The article is devoted to the study of ways of developing media creative competencies of students of the University of Law with helping authoring tools. An example of teaching the training module "Information and Communication Technologies" using authorial tools is shown and the effectiveness of the application of teaching methods in the development of students' media creativity is proved.
\end{abstract}

Keywords: competency-based approach, media creativity, authoring tools, post-experimental survey, correlation.

\section{INTRODUCTION}

The system of higher education in many countries of the world is currently gradually shifting to development based on advanced learning trends, which giving significant qualitative changes associated with an ever-increasing personal adaptability and orientation of educational processes. Global socio-economic and scientific-technical changes require improved management of the training system for future specialists based on the competency-based approach of education. Today, in the educational standards of developed countries, such as the USA, England, Germany, China, Japan, special attention is paid to the formation of global students' skills. For this, it is important to modernize the content of existing vocational education, training technologies and assess learning outcomes based on a competency-based approach.

At the same time, the development of new pedagogical paradigms and authoring tools is crucial for the development of media creative competencies of students. According to this and international pedagogical experience, the implementation of new pedagogical projects and the introduction of innovative achievements in the educational process provides an effective opportunity for the formation of media creative competencies for law students.

\section{MATERIALS AND METHODS}

As a result of the rapid development of science and technology, today the volume of scientific knowledge, concepts and ideas is growing. In these circumstances, the demand for creative staff is growing and requires a high level

Revised Manuscript Received on November 18, 2019.

* Correspondence Author

Pozilova Shakhnoza Khaydaraliyevna, Ph.D, Department of Information technologies on education, Tashkent State University of Law, Tashkent, Uzbekistan.

Karimov Akramjon Zaynobidinovich, Associate professor, Department of "General Sciences", Tashkent State University of Law, Tashkent, Uzbekistan. of professional competence. Higher education plays an important role in modern society. The rapid development of any country, the basic and undeniable intellectual capacities is achieved through the reform of the education system. Through the education of citizens, the state economy and society improve their livelihoods, and emerging technologies demonstrate the need for higher education in the world markets [1], [2].

Media creativity is the basis for the development of competitiveness not only of individual enterprises, but of the national economy.One of the main tasks of the modern education system is formation of specialists with media creative competencies. This task can only be achieved by developing prospective lawyers' skills in media creativity through author's tools, allowing the learner to grasp new knowledge, to innovate and to apply them effectively.

That is why in recent years, concepts like media, creativity and competence have been embedded in the learning process.Scientists of the Republic and foreign countries have done a number of scientific researches on the characteristic of philosophical, psychological and pedagogical aspects of contexts.

According to Y.M.Asadov, one of the most valuable features of creativity is its key role in creating innovation. Innovation is a product of the intellect of the individual manifested by the use of creativity [3].

G.N.Ibragimova's research suggests that creativity is a set of skills related to personality, creativity, and creativity, which includes a high level of sensitivity to problems, motivation, predictability, fantasy, research, and reflexivity [4].

A.A.Aripzhanova, taking into account the peculiarities and approaches of pedagogical activity in the study of creativity, found that it is necessary to consider the creativity of pedagogical staff: active, effective, personal, environmentally, problematic aspects [5].

The introduction of an online component in training will increase the student's motivation for the subjects of the lesson, and the teacher will work with students adaptively and personality-oriented with a system-competency-based approach.

More than a hundred definitions of the concept of creativity in various dissertation studies, including E.S.Shelestova [6], N.A.Stepanenko [7] and others. According to many authors, creativity is closely linked to the activities of higher education institutions in the pedagogical process, which is a key condition for the educational process and economic modernization. At the same time, one of the key 
factors for improving of the HEI' effectiveness is the modernization of the system of material and technical capacity [8], [9], [10], [11], [12].

Media - helps students and students to take a critical look at the media, understanding the media content in their lives. The media or student should have a critical or analytical approach to media or student assessment, be critical in relation to popular culture, and resist manipulation [13].

Media literacy is the ability to interpret or analyze and create media files. Media literacy is the ability to obtain, analyze, evaluate and transmit information in various forms [14].

Media reading is an effort to help people understand, create, and evaluate the cultural significance of the audiovisual and printed texts. Anyone can become a media reader [15].

The border between media skill and media education is very smooth and interchangeable. K.Worsnop (Ch.Worsnop), V.Gura, V.Monastyrski, A. Korochensky, J.Panjente (J.Pungente), S.Penzin, I.Rozer (I.Rother), D.Suuss (D.Suess) ), L.Usenko, T.Shack and other media educators believe that media education is the result of media education. According to D. Lemish, media education is a more comprehensive concept. It cannot be explained by simply linking it with media education. According to A.V.Fedorov, these two concepts should not be separated [16;17].

Competence is not the acquisition of individual knowledge and skills by the student, but rather the integration of integrative knowledge and actions in each independent direction [17].

In Markova's case, professional competence is considered as a special subject in the context of labor psychology [18].
During this period, as well as those related to teacher competence, LM Mitina, LA Petrovskoy, N.V. Performed by Kuzmina, LP Alekseeva, NS Shabligina and others. Another development of this approach is that the UNESCO materials and documents have begun to provide a range of competences as a learning outcome.

In the scientists' researching works, about ten-year-old, development of student creativity, the use of authoring tools was almost not considered and transformed, and the concept of "media creativity" appeared relatively recently.

Summarizing the above considerations, we define the term "media creativity" as the work of future lawyers to use the media to create new, original ideas as a result of non-standard thinking, and the "media creative competence" is using the result of the action in practice as acmeologically. Formation of media creative competence of lawyers in the information society, using ICT tools in practice, will contribute to the further development of the country.

In our opinion, media creative competencies, developing divergent thinking and digital literacy, can grow to a strong ability to produce a large number of unusual and non-standard ideas.

\section{DISCUSSION}

The rise of innovative pedagogical activity is based on the fact that the creation of new aspects of education and upbringing is the creation of an optimal form of the importance of innovative technologies based on unconventionality and originality, and most importantly, the ability to think, nurture and understand. The article explains the features of the formation of mediocre- mental competences of undergraduate students. (Table 1.).

Table 1:Features of the formation of media creative competences of students studying in the direction of law

\begin{tabular}{|c|c|}
\hline Criteria & Mediacreative competences \\
\hline $\begin{array}{l}\text { The purpose of } \\
\text { education }\end{array}$ & $\begin{array}{l}\text { Development of mediocre competence and creativity of students in the } \\
\text { information society. Creating and integrating innovation into the learning process. }\end{array}$ \\
\hline Teaching activities & $\begin{array}{l}\text { Use innovative programming to develop innovative and mediocre competence of } \\
\text { students }\end{array}$ \\
\hline Student activity & Be active so that students can generate new ideas and apply them in practice. \\
\hline Forms of education & Group, invidual, collaborative. \\
\hline Teaching methods & $\begin{array}{c}\text { Authoring tools (Articulate Storyline, Powtoon, Sparkol), problem-solving, } \\
\text { design, creative teaching methods. }\end{array}$ \\
\hline Educational tools & Use of network technologies, electronic and mobile technologies. \\
\hline $\begin{array}{l}\text { Performance } \\
\text { evaluation }\end{array}$ & Self-monitoring and evaluation. \\
\hline
\end{tabular}

Formation of media creative competencies for law students in higher education institutions will stimulate students' interest and desire for active life in the innovative community, encourage thought-analysis, and reinforce their feelings and knowledge.

The implementation of the student's media creativity development must be conducted in parallel with the training to observe ethical and legal norms, to precaution in network interactions.

In order to conduct activities in the rule of law, adhering to the principles of justice, future lawyers, along with analysts, need to increasingly strengthen the competence of creativity.

Creativity eliminates the habit of memorizing, giving an impulse to think. 
A creatively minded lawyer, with full digital literacy, has expanded horizons, a sense of civic duty, strong networking skills, search and information fluency, modeling and decision-making skills. In particular, the media creative competence of a lawyer expands his range of opportunities to use various software innovations in their activities.

Table 1. Indicates that modern information and communication technologies (ICTs) play an important role in education. Modern ICTs can provide new opportunities for creative thinking, as well as new forms of access to ideas and resources, including information.

At the same time, the use of specialized training platforms (Koh JHL, Chai CS, Benjamin W.) [19], open educational resources (Kaatrakoski H., Littlejohn A., Hood N.) [20] and mobile applications (Anohah E ., Oyelere SS, Suhonen J., Sutinen E.) [21], designed to ensure the implementation of innovative forms and methods that can help identify and build competencies and creativity in particular, depending on personal inclinations and interests.

The implementation of this methodology resulted in methodological projects that reveal various didactic possibilities of using modern information and communication technologies. For example:

- the use of http://en.linoit.com/, http://ru.padlet.com or http://wikiwall.ru/ not only as a tool for the joint creation of thematic online newspapers, but also for the creation of various didactic tasks and its joint performance or joint recall to something;

- Creation of interactive didactic tasks based on http://learningapps.org/ or http://studystack.com ;

- Creation of animated presentations of students based http://powtoon.com or http://sparkol.com ;

- Creation of thematic forums based http://www.forum2x2.ru ;

- Collective creation of clusters based http://mindmap.com, etc.

At the same time, students noted that the formation media-creative competencies with the help of authoring to helped them realize the originality of using Inter technologies for various didactic purposes - provid educational information and its joint analysis, managing joint educational process and organizing joint projects with reflection and monitoring of achievements.

\section{RESULT}

To confirm the effectiveness of the developed methodology, a pedagogical experiment was conducted, which took place from September to December 2018-2019. In total, 380 students at Tashkent Law University took part in the experiment.

The experiment was conducted on the example of "Information and Communication Technologies". At the same time, Powtoon was chosen from the authors' tools to build mediocre competences of students.
Powtoon is a service that is a tool for creating animated presentations. It allows you to create free and amazing animated videos and positions itself as an alternative to PowerPoint. PowToon is able to create: Presentations for sales. Video for landing pages 1.

Comparison was made with groups where teaching according to the traditional methodology.

Teaching in the experimental and control groups was conducted by students of the same qualification category. The number of students in control groups was 32 , and the number of students in experimental groups was 31 .

To assess the effectiveness of the developed provisions on the use of authoring tools, we used an indicator of the dynamics of changes in their knowledge and media creative competencies: 5 - high, 4 - medium, 3 - low, 2 - zero.

The fact that the degree of preparedness of law students of the experimental and control groups is the same is shown by the results of Table. 2 and the range of relative frequencies (Fig. 1).

Table 2: Statistical data of the experimental and control groups prior to the experiment

\begin{tabular}{|c|c|c|c|c|c|c|c|c|}
\hline Statistical data & \multicolumn{3}{|c|}{$\begin{array}{c}\text { Experimental } \\
\text { group }\end{array}$} & \multicolumn{3}{c|}{ Control group } \\
\hline Indicators & 5 & 4 & 3 & 2 & 5 & 4 & 3 & 2 \\
\hline Number of students & 5 & 21 & 3 & 2 & 6 & 17 & 9 & 0 \\
\hline $\begin{array}{c}\text { Total number of } \\
\text { students }\end{array}$ & \multicolumn{3}{|c|}{31} & \multicolumn{5}{|c|}{32} \\
\hline Sample averages & \multicolumn{3}{|c|}{3,94} & \multicolumn{3}{|c|}{3,91} \\
\hline Sample variance & \multicolumn{3}{|c|}{0,51} & \multicolumn{5}{c|}{0,46} \\
\hline
\end{tabular}

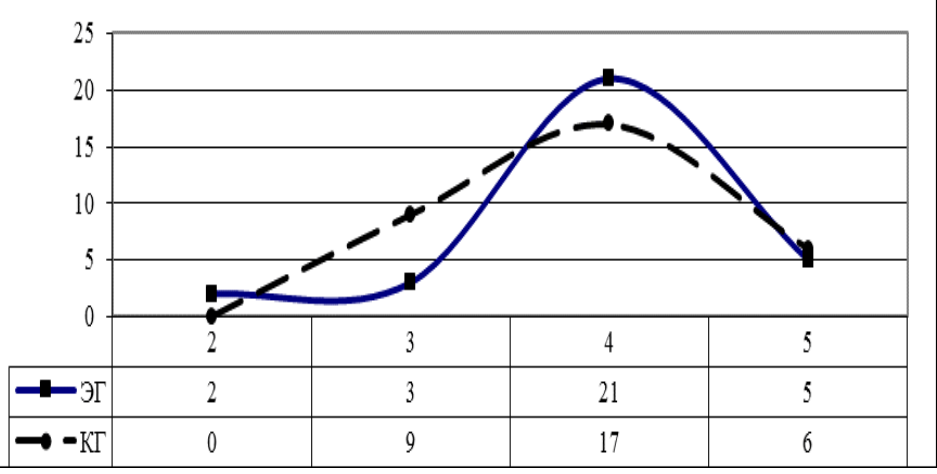

Fig. 1. Relative frequency polygons

At the end of the training period, sections of the test tasks in the experimental and control groups were performed. The results of the verification work of the experimental and control groups were processed based on the student criterion (table. 3). 
Table 3: Statistical data of the experimental and control groups after the experiment

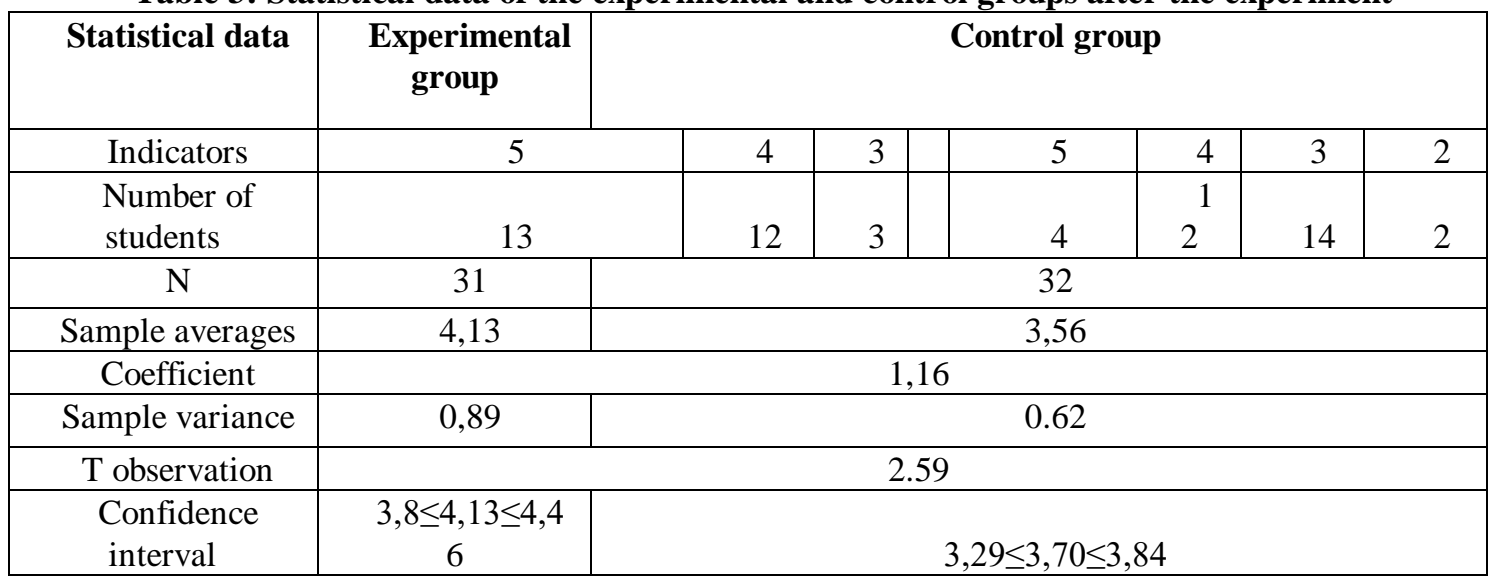

The results of the table show that the increase in the media creative competencies of students of the law University of the Experimental Group is $16 \%$ higher in relation to the control group, which is a consequence of the introduction of the authoring tools for increasing media creativity competence of students.

A post-experimental survey of participants' shows that the correlation between engagement and time spent on self-education in the experimental group (0.89) turned out to be much higher than the correlations in the control group (0.63). Moreover, the correlation index in the experimental group is positive-strong. This argument makes it possible to boldly introduce into the system of higher legal education a methodology for the formation of media creativity competencies among students-future lawyers using copyrighted tools, and therefore, to develop appropriate didactic support.

\section{CONCLUSION}

As a result, based on the results of the study, we can conclude that, in order to consolidate the holistic system of competencies of future lawyers, training in authoring tools in law schools should be introduced in a systematic way. And also, the didactic support of the tasks of forming media creative competencies should be improved with the help of authoring tools taking into account the integrative assimilation of academic disciplines. The use of authoring tools in the higher education system contributes to the development and strengthening of creative abilities, overcoming stereotypes in the choice of alternative means, methods and methods of training, developing the skill of an innovative approach to professional and other various situations among both students and teachers. The given experiment confirmed the correctness of the design of the authors of the article by teachers - the methodology developed by them for using copyright tools for the development of media creativity for law students turned out to be acceptable and effective in teaching the educational module "Information and Communication Technologies". And also, this technique can be used to organize blended learning and self-education of students in other educational modules located in blocks of general methodological and special disciplines of the university curriculum. The purposeful use of this methodology and the author's tools themselves to build media creativity competency among students entails the development of such features of students' abilities as originality, development, fluency, flexibility and critical thinking in the context of individuality, and also provides a strong prerequisite for the teachers themselves to form educational skills and improving the creativity of thinking in the process of teaching.

\section{REFERENCES}

[1] Korotkov E.M. Quality management of education: Textbook for universities. - M.: Academic Project, 2006. - 320 p.

[2] Skidin O.L. Education management: theoretical-methodological analysis of social technologies. M .: PGI. - 2000-291s

[3] Asadov Yu.M. The individual psychological characteristics of the teacher as factors in the development of professionalism: Author's abstract. ... cand Psycho. sciences. - Tashkent: "NUUz", 2007.-25 p.

[4] Ibragimova G.I. Developing students' creativity skills based on interactive teaching methods and techniques: Doctor of Philosophy $(\mathrm{PhD})$. autoref. $-\mathrm{T} .:-2017 .-24 \mathrm{p}$.

[5] Aripzhanova A. R. Development of creative potential of teachers of higher educational institutions in the conditions of informatization of education. p.f. Doctor of Philosophy (PhD). autoref. T .: - 2017. 24 p.

[6] Shelestova E.S. technology formulation of creativity of students-designers in the process of professional training. Autooreph. kand.ped.nauk. - M. 2014. - $231 \mathrm{pp}$.

[7] Stepanenko N.A. Developing creative competences of students of pedagogical support. - Autoref. kand.ped.nauk. - Orsk: - 2015. -215 p.

[8] Ahmetova D., Gure L. Prepodellar Vose and Innovation Technology // Высшее образование в России. - 2001.- No. 4. Pp.138-141.

[9] Ball G.A., Bastun MV, Gordienko VI, Krasilnikova GV, Krasilnikov S.G. Psychology troupe and professional podgotovki lichnosti // Academy of Education of Ukraine, Institute of Pedagogy and Psychology professional education. 2014. $158 \mathrm{c}$

[10] Gershunsky B .S. Obrazovatelno-pedagogical forecasting . Theory, metrology, practice // Учебное пособие. - М.: Nauka, 2003. - 768 pp.

[11] Clarin M.V. Innovations in Mirovoy Pedagogy.-Riga: NPT Experiment, 1995. - 176 р. [12] Мамыкин И. На пути к креативному обучению: вопросы методологии и методики // Философские традиции и современность - 2015. - №2(8). - C.97-103. URL https://elibrary.ru/item.asp?id=25447757.

[13] Duncan, B. (Ed.). Media Literacy Resource Guide. Toronto: Ministry of Education of Ontario, Publications Branch, the Queen's Printer. 1989. $232 \mathrm{p}$.

[14] Silverblatt, A. (2001). Media Literacy. Westport, Connecticut - London: Praeger.

[15] Kuronov M. The article "The Internet is a Scapegoat for Simple Young People, a Media Scam" From the Book World. http://vatandosh.uz/news/2014/02/23047/ [16] Fedorov A.V., Novikova A.A. Media Jobs in Vegetable String - monograph // Taganrog: Izd-vo Kuchma, 2005. - 71b.

[17] Fedorov A.V. Media Jobs in zarubejny stranax. monograph // Taganrog Izd-vo Kuchma, 2003, - P.238.

[18] Markova A.K. Psychological analysis 1990. No. 8. 
[19] Koh J. H. L., Chai C. S., Benjamin W. Technological Pedagogical Content Knowledge (TPACK) and Design Thinking: A Framework to Support ICT Lesson Design for 21 st Century Learning // The Asia-Pacific Education Researcher. - 2015. - Vol. 24, Issue 3. - P. 535-543. DOI: http://doi.org/10.1007/s40299-015-0237-2

[20] Kaatrakoski H., Littlejohn A., Hood N. Learning challenges in higher education: an analysis of contradictions within Open Educational Practice // Higher Education. - 2017. - Vol. 74, Issue 4. - P. 599-615. DOI: http://doi.org/10.1007/s10734-016-0067-z

[21] Anohah E., Oyelere S. S., Suhonen J., Sutinen E. Trends of mobile learning in computing education from 2006 to 2014: A systematic review of research publications // International Journal of Mobile and Blended Learning (IJMBL). - 2017. - Vol. 9 (1). - P. 16-33. DOI: https://doi.org/10.4018/IJMBL.2017010102 